BESL-S(1)=2S

Built-Environment:Sri Lanka -Vol. 03, Issue 01:2002

\title{
INDO-LANKA DEVELOPMENT CORRIDOR Conceptual issues
}

\author{
Willie Mendis
}

\section{ORIGINS OF THE "IDEA"}

The Govemment of Sri Lanka has forecast that by 2010 , almost one half of Sri Lanka's total estimated population of twenty million will be living in areas where urban characteristics are dominant. (NPD, 2001).

This trend has been manifest in all developing countries, including India. The United Nations has projected "that by the end of the first quarter of the twenty first century about half of India's population would be in cities and towns." (Rebeiro, 1977).

The crossing of the 'nascent stage of urbanisation' and the growing integration of the world economy in the phenomenon of globalisation have prompted analysts to conclude that "city regions are perceived as the fundamental spatial units of the global economy and as political actors on the world stage". (Sassen 1994). Consequently, the emergent mission by nations has been to achieve economic growth through developing a city's competitive advantage.

A noteworthy event which took place around this time was the hosting of an International Conference on "Cities and the New Global Economy" presented by the OECD and the Australian Government in Melbourne in November 1994 A key rationale at same was that "policy must take account of the spatial character of economic development" (OECD, 1995). Moreover, that "Cities can no longer be considered predominantly or exclusively within a national system." (OECD, 1995). The latter was re-inforced by several papers presented at the Conference, notably those that highlighted transborder urban corridors including that of BESETO (Beijing-SeoulTokyo), and SIJORI (Singapore-Johore (Malaysia) Riau Archipelago (Indonesia).

The above Conference infused the notion that the urbanization process is irreversible as attempts to prevent urbanization have all proved to be ineffective in the long run, Its challenge was to maximize benefits while minimizing the costs. For same, a critical leverage was the competitiveness of the national urban system in the global economy. It's key was that city regions be on the scale of agglomerations to enable functional diversity in the cityscape

The author's research agenda on the urbanization pattem and trends in Sri Lanka was driven by the above in seeking ways and means of linking same with policies for economic growth. The immediate limitation was the size of the total population in cities outside the Colombo Metropolitan Region. Hence, in the context of physical assets which could facilitate the benefits of globalization, such as Seaports, Airports, and Free Trade Zones, it became evident that it was necessary to derive a synergy between each of these and its corresponding city. The latter was further re-inforccd by the popular view that Colombo should be made an "Asian Financial Centre" and that its Seaport should be a "Regional Hub".

The challenge for the above was evident from two major events that influenced the research agenda:

i. National Conference on Role of Seaports in Economic Development organized by the Institute of Towti Planners, Sri Lanka, June 1998.

ii. International Conference hosted by COPEDEC (Coastal \& Port Engineering in Developing Countries) in Cape Town, South Africa, April, 1999.

The deliberations at these two Conferences prompted the overspill of the emergent National Spatial Design of Urban Agglomerations and Expressway Network (Figure 1), to seek transborder opportunities with the Southem States of India, which had significant shares of urban population (Table I). The latter was reinforced by the following which also impacted the research agenda during this time:

i. The launching of the Indian Highway Network linking North-South and East- West of that country.

ii. The success of the Hi-tech Parks in Bangalore and Hyderbad.

iii. The signing of the Free Trade Agreement between India and Sri Lanka

N. The proceedings of the $46^{\text {th }}$ National Town and Country Planners Congress in Mysore.

The congruence of the research process from the time of the Australian Conference through the other events mentioned above resulted in the embryonic development of the idea of linking Sri Lanka's urban system with that of the Southern Indian States. It's immediate consequence was the conceptualization of a "bridge" across the Palk-Straits dividing India and Sri Lanka (Figure 2). 
It was aiso reported that there had existed in the 1960s a proposal attributed to the United Nations Economic Commission for Asia and the Far East (ECAFE) "to establish an Asian Highway Network from Indonesia, Singapore, Malayasia, Burma, through India, Nepal, Pakistan, Afghanistan, Iran to the borders of Turkey called the A-I Network and an A-2 from Iraq which would carry a spur from North India through to Cape Comorin and across the then Ferry to Ceylon as it was known" (Suriyakumaran, 2002). It's rationale though different at the time had a link between India and Sri Lanka. Hence it is apparent that the antecedent of the latter idea can be dated back to four decades.

\section{THE SETTING}

Meanwhile during the on-going research on the transborder urban corridor, a noteworthy occurrence with massive ramification comprised the publication of a News item in December 1998 indicating that India was inducting the 'Sethu Samudra Ship Canal Project'. It's aim being to "deepen the territorial water of India, running through the Gulf of Mannar and the Palk Strait in order to facilitate ship movement through this waterway in the style of other man-made canals like the Suez and Panama" (Nair, 1998). The project if implemented according to the letter of the law would in the future reduce the circumnavigation of ships in the Indian Ocean to take full advantage of this shorter route. It's ramification will then make Colombo Port valueless to the cost-conscious shippers. It's overall impact becomes evident when considering the fact that $70 \%$ of the containers handled in Colombo were transhipment cargo generated from Sri Lanka's external trade \& the growth of the demand in the region, especially from India. In fact "South Asia which is the traditional hinterland of Colombo Port is one of the most rapidly developing economic growth areas in the world" (Ministry of Shipping, 1977). The latter segment will gradually disappear from Colombo's Seaport if the canal project is implemented resulting in a massive shock to Sri Lanka's vulnerable economy.

Furthermore, other News items reported extensively about the environmental hazards for Sri Lanka and Tamil Nadu arising from excavating the Palk Straits (Zubair, 1999, Wickremasuriya, 1999). The Sethusamudram Canal Project would also terminate the notion of a "bridge" forming the centerpiece of the transborder urban corridor.

The more recent resuscitation of the notion of the "bridge" in bi-lateral talks between the Prime Ministers of India and Sri Lanka has regenerated its interest. They have agreed to undertake a "feasibility study" which is reportedly to be jointly discussed in February 2002.

Meanwhile, the environment in which the entire concep of the link between the two nations has evolved lie against the backdrop of the 19-year "Separatist Conflict" in the North and East of Sri Lanka in which India's role in its early years had created much public concern. Hence, several public and professional seminars/ meetings at which the transborder concept has been presented in Sri Lanka have evoked mixed reactions. A recently published letter in a Newspaper vents the deep feelings of a reader (Goonewardene 2002).

On the other hand, the Government of Sri Lanka and the international community, including India, are relying on the environment being conducive to securing peace between the conflicting parties. In overall terms, other areas of closer collaboration with india are also being pursued including visa-free travel and an "Open Skies Policy for Air Travel". The Free Trade Agreement between the two countries is already in place. Accordingly, the groundwork for examining the feasibility of the transborder link is being gradually laid. The research agenda has also deemed it appropriate to call it a "Smart Partnership Project", in line with Malaysia's terminology for cross-border investment projects.

\section{THE CONCEPTUAL FRAMEWORK}

As indicated in the previous section the "transborder bridge" was proposed only as a means for realizing the end. The latter being to re-inforce the networking of the city-regions in Sri Lanka and of India with special reference to the Southern Indian States. The aim of same being to create the conditions conducive to economic growth in both nations. The conceptual framework for its enablement is the formulation of a preferred Spatial Development Strategy in the transborder corridor. The analysis of the issues involved in such an excersise is compellingly multidisciplinary, which is often overlooked in favour of a particular discipline during the stage of undertaking the Feasibility Study of mega-projects. The latter was a classic omission in the massive multi-purpose Mahaweli Development Project which focused itself on dams, reservoirs, and power-stations thereby marginalizing the source of development, i.e. the human settlements and their networks. In same, the nation thereby missed the vast opportunities that could have accrued from incorporating the Colombo -Trincomalee development corridor as an integral part of the Accelerated Mahaweli Project (Mendis, 1973). The repetition of such omissions in the Indo-Lanka Project by focusing dominantly on the "bridge" will be a mistake of catastrophic proportions.

The inclusion of the Spatial Development Strategy as the backbone for economic growth will facilitate the translation of the objectives of the transborder link for achieving its overall goal. The thrust of the latter will be on Communications and Uiban Development; both of which will be driven by investment flows. Consequently, the strategic urban nodes will become receptors for Transport Infrastructure, IT Parks, Construction, and Financial Services. It is for such reason that the transborder corridor will have to possess the economies of scale to attract investment flows. The yardstick for same being the magnitude of the share of the urban population in the corridor which presently has an urban catchment exceeding 77 million. It's competitiveness will arise from the capacity of city-regions in the corridor to develop as "global cities" with vast reservoirs of skills essential for a knowledge-based new economy. 
The transformation of the above into the ground situation suggests that the imminent zone of influence of the transborder link on the Indian side would be the eastem seaboard of the Tamil Nadu State, spanning from Tuticorin to Madras. It's zonal belt on the east-west axis may traverse westward upto Bangalore in Karnataka State, and on the north-south axis may stretch as far north as Hyderbad in Andhra Pradesh State and to Trivandrum in the Kerala State. In macro-terms, the entirety of the city-regions in India could relate to the transborder corridor. The relevance of the latter will be apparent in the context of an "estimated $40 \%$ of India's Bilion-plus population being Urban by the year 2021 in which there will be at least seventy Million-plus Cities" (Suresh, 1999). The connectivity of same by the previously mentioned Indian Highway Network will catalyse its impact on the corridor.

The spatial fabric of the zone of influence on the Indian side could be arranged under sub-regions according to the intensity of the impact on the "transborder corridor" It's further analysis on same could be entrusted to the Institute of Town Planners, India.

On the Sri Lanka side of the transborder link, the key city-regions will comprise the Colombo Metropolitan Region and the Trincomalee Metropolitan Region. These can be connected to the other key urban nodes of the Southem Region, Triple-KRegion, and the Jaffna region by the Colonibo-Hambantota and Colombo-Trincomalee Expressways, with rapid transit access to Jaffna linking the route connecting the Rameshwaran-Mannar bridge to Trincomalee. (Figures 1 and 2; Table 1)

The Spatial Development Strategy which manifests the above conceptual framework has been aptly described as the BAMATRICO development corridor to suggest the relatively greater importance of Bangalore, Madras, Trincomalee and Colombo (Mendis, 1997).

\section{THE "SMART PARTNERSHIP" CONCEPT}

As previously mentioned, the conceptualisation of the "bridge" was essential to mitigate the vulnerability of the Port of Colornbo arising from the Sethusamudram Canal Project. The initiation of the latter for Defence purposes may have been otherwise driven by the proposed development of the Tuticorin Port in collaboration with the Port of Singapore Authority (PSA). Accordingly, in this situation, there are several favourable reasons for the inclusion of Singapore in the envisaged "Smart Partnership" project for the development of the transborder corridor.

Singapore is a city-state with a proven ability in successful urban-led development. It is an acknowledged "global city" with the experience of transborder development. Further, it too had developed on information technology, construction, port development, commercial aviation, and Financial Services. Consequently, its already prevalent collaboration with India in several of these sectors in the "new economy" establishes its credentials as the most favoured for involvement in the "Smart Partnership" project. It's own role as the "gateway" to South East Asia will further enhance the opportunities in the transborder project. In these circumstances, the reported support of Singapore for the "transborder-bridge" project announced during a recent meeting between the Prime Ministers of Sri Lanka and Singapore, augurs well for the establishment of a tripartite pact for the proposed venture. ${ }^{21}$

Sri Lanka has now assumed the key role as the Promoter of the Smart Partnership. The inherent nature of the latter has all the characteristics for their respective economies to be inter-twined with that of an emergent process that will have irrevocable implications. Consequently, the absolute clarity of the objectives of the proposed venture is a pre-requisite in the next stage of its undertaking, viz, the feasibility study.

\section{THE FEASIBILITY STUDY}

As previously mentioned, India and Sri Lanka have agreed to commence discussions on matters pertaining to the undertaking of the Feasibility Study for the project. In same, the "bridge" alone will not represent the totality of the venture. It's tangible direct returns may include the Toll from those who use the bridge. On the other hand, the revenue generation from the inland container depots, value - added industry, telecommunications , railway, tourism, financial services, trading, and construction may also need to be included in the computation of the returns. In this connection it is noteworthy that a proposal has recently been made for a Trans-Wilpattu railway line in Sri Lanka to connect with the "Transborder bridge" which could also promote Hindu pilgrim traffic from Chennai to Kataragama. A strong case has further been made to extend the scope of the Feasibility Study to include power development "arising from the hydraulic differences that exist across the gaps in the reef along Adam's Bridge, some of which falls within the territorial boundary of Sri Lanka" (Wickramasuriya, 2002). The enveloping of all of them in urban development will provide the most appropriate basis for evaluating the feasibility of the proposed venture. The above suggests the relevance of the proper conceptualization of the project to enable the capture of the full spectrum of the benefits and its returns.

\section{CONCLUDING COMMENTS}

The concept of a 'transborder bridge' has opened an entirely new vista for the island. It offers a $21^{\text {st }}$ century vision which need to be steered in the appropriate manner. It's opportunity may also be taken to be rid of the "Island mentality" and become a respected nation in the world stage. 
TABLE 1

URBAN SHARES IN SOUTHERN STATES OF INDIA

\begin{tabular}{|llll|}
\hline STATE & $\begin{array}{l}\text { TOTAL } \\
\text { POPULATION } \\
\text { MILLION }\end{array}$ & $\begin{array}{l}\text { URBAN } \\
\text { POPULATION } \\
\text { MILLION }\end{array}$ & \% OF TOTAL \\
\hline KERALA & 31.84 & 8.27 & 25.97 \\
TAMILNADIJ & 62.11 & 27.24 & 43.86 \\
KARNATAKA & 52.73 & 17.92 & 33.98 \\
ANDHRA PRADESH & 7573 & 20.50 & 27.08 \\
\hline TOTAL & 222.41 & 73.93 & 33.24 \\
\hline
\end{tabular}

SOURCES: CENSUS OF INDIA 2001, (Provisional)

Note:The supply of information by the High Commission of India in Sri Lanka and the Institute of Town Planners, India, is acknowledged.

TABLE 2

POPULATION SHARES IN URBAN AGGLOMERATIONS OF SRI LANKA

\begin{tabular}{|llll|}
\hline URBAN AGGLOMERATION & $\begin{array}{l}\text { TOTAL } \\
\text { POPULATION } \\
\text { (MILLON) }\end{array}$ & $\begin{array}{l}\text { URBAN } \\
\text { POPULATION } \\
\text { (MILLION) }\end{array}$ & \% OF TOTAL \\
\hline COLOMBO METROPOLITAN REGION & 4.60 & 2.35 & 51.0 \\
SOUTHERN DEVELOPMENT REGION & 2.28 & 0.26 & 11.4 \\
TRIPLE - K REGION & 3.50 & 0.28 & 8.0 \\
TRINCOMALEE REGION & 0.26 & 0.08 & 31.0 \\
JAFFNA REGION & 0.83 & 0.27 & 33.0 \\
\hline \multicolumn{1}{c}{ TOTAL } & 11.47 & 3.24 & 35.4 \\
\hline
\end{tabular}

\section{SOURCES:- CENSUS OF SRI LANKA 2001, (Provisional)}

Note:- Populations of Southern Development Region \& Colombo Metropolitan Region were sourced respectively from the JICA Master Plan (p.4-47)* and Colombo Metropolitan Regional Structure Plan Vol. 1(p.8)**

* Japanese International Co-operation Agency (1995), The Master Plan Study for Southern Area Development, Sri Lanka.

** Urban Development Authority (1998), Colomho Metropolitan Regional Structure Plan Vol 1; Synthesis. 


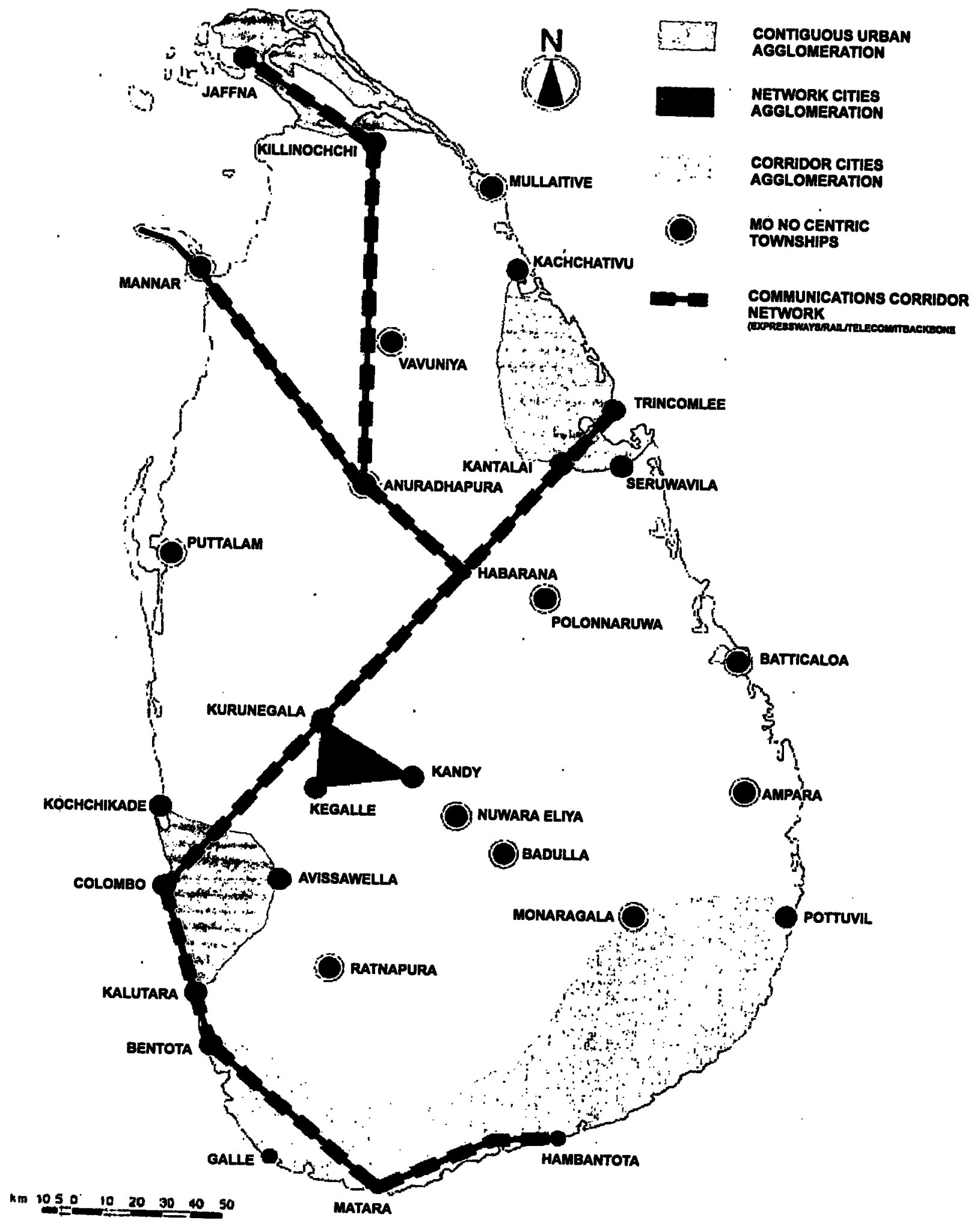

Figure 1 - SPATIAL CONFIGURATION - SRI LANKA YEAR 2020 


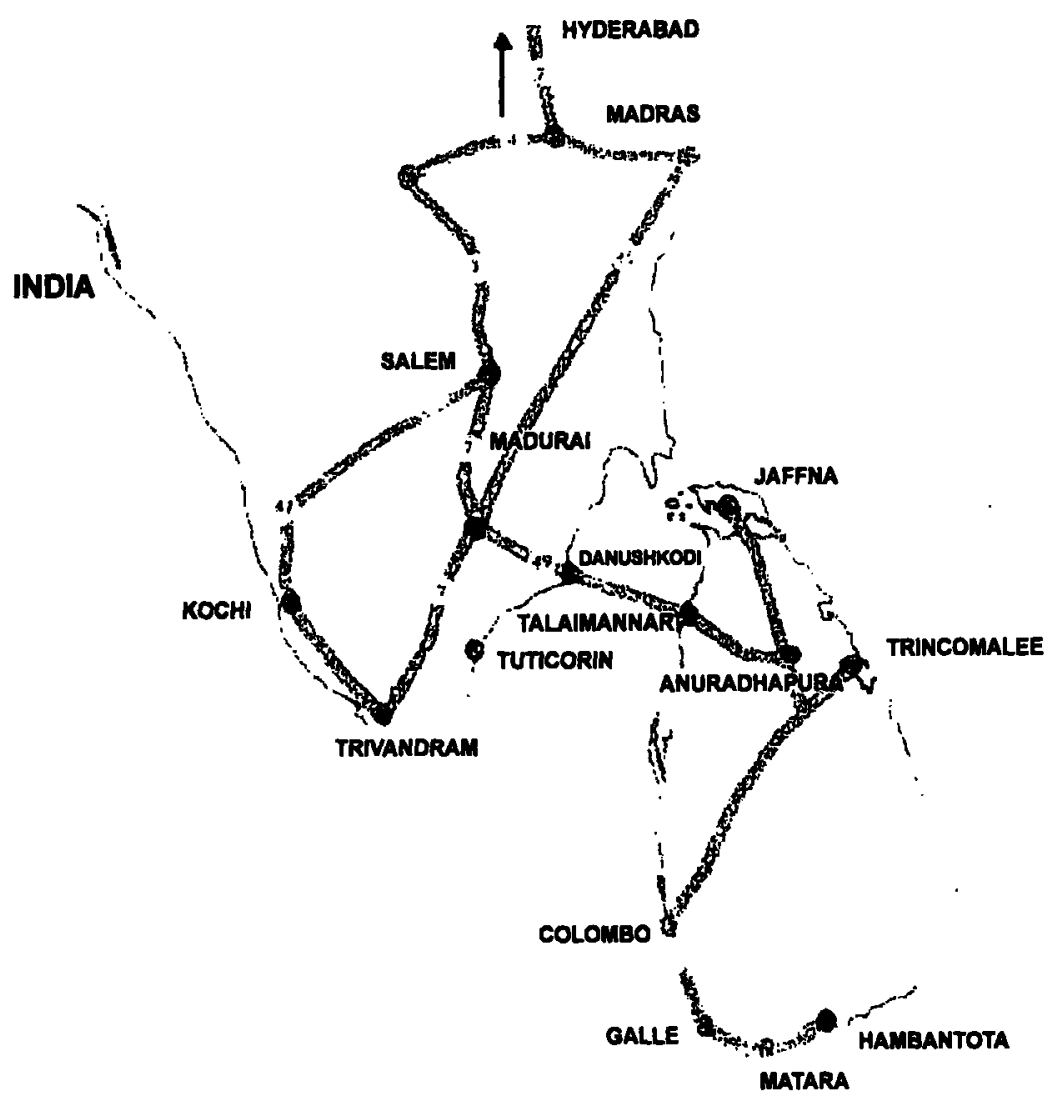

Figure 2 - PROPOSED INDO - LANKA "SMART PARTNERSHIP" PROJECT

References

National Planning Department, 2001, Vision 2010,

Sri Lanka, Ministry of Finance \& Planning, Colonibo.

Sri Lanka, p. 146.

OECD/Govt. of Australia (1995) International

Conference on "Cities and the New Global Economy".

Conference Proceedings, Volume I, Australian

Government Publishing Service, Canberra, Australia,

p. iii.

Surlyakumaran, C, The Indo-Lanka Bridge \& the

Asian Highways, in Daily News, 23 March 2002.

Nair. G.N.; Expect the Unexpected, in The Sunday

Leader, 6 December, 1998.

Ministry of Shipping \& Ports, Sri Lanka (1977),

National Ports \& Shipping Policy of Sri La,ika.

Zubair. Lareof, (1999) Hazards for Sri Lanka \& Tamil

Nadu From Excavating the Palk Straits, in Sunday

Island of 14 February1999.

Wickremasuriya, ATGA.. (1999) Will the Waming

Given Fifteen Years Ago Continue to Fali on Deaf

Ears in the lsland, of 22 May 1999.

Mendis, M.W.J.G., (1973), The Planning implications of the Mahaweli Development Project in Sri Lanka, Lake House Investments Ltd. (Publishers), pp. 105 $\& 106$.

Suresh. V., (1999), Chairman/Managing Director, Housing \& Urban development Corporation Ltd., India in Paper presented at CHEC/Commonwealth Business Forum, Johannesburg, South Aftica, pp. $3 \& 4$.

Wekramastiriya, ATGA (2002), Scope for a multipurpose road and power development between India \& Sri Lanka in Island of 20 February 2002. 